\title{
China, India, and the Socioeconomic Determinants of Their Competitiveness
}

\author{
Claudia Grupe and Axel Rose \\ Comparison and Transition of Economic Systems, Goethe-University Frankfurt, Dantestraße 9, 60325 Frankfurt, Germany
}

Correspondence should be addressed to Claudia Grupe, cgrupe@wiwi.uni-frankfurt.de

Received 4 April 2010; Accepted 27 July 2010

Academic Editor: Ussif Rashid Sumaila

Copyright ( 2010 C. Grupe and A. Rose. This is an open access article distributed under the Creative Commons Attribution License, which permits unrestricted use, distribution, and reproduction in any medium, provided the original work is properly cited.

We analyze and compare the social, cultural and historical determinants that influence the international competitiveness of China and India. Starting with the discussion why pure economic determinants cannot solely explain a country's competitiveness, we will analyze previous qualitative research and evaluate quantitative data to assess which country has more favorable socio-economic factors influencing its economic performance in the long run.

\section{Introduction}

Few days pass without a headline on China and India in the global press. The Economist stands not alone asking "What's to stop China and India?" (Edition of 27.10.2005). The world's workbench and its research laboratory do not only fascinate investors, politicians, or scientists, but also the general public.

The People's Republic of China and the Republic of India are not only the two most populous states in the world, but also two of the fastest growing economies in the last years-and increasingly important engines of the globalized economy. China has been growing with nearly two-digit rates since the first reforms in 1978 and is the world-leading receiver of foreign direct investment today. Since 1980, India has been generating an average real growth of $6 \%$ per year, constantly surpassing the $8 \%$ landmark since 2003 . In the years to come, economists still expect growth rates above the global average. Wilson and Purushothaman [1] in their famous BRIC study for Goldman Sachs even estimate China to be the world's largest economy by 2039 , followed by the United States and India.

For these reasons, there is a large and steadily growing number of (popular) scientific publications on China and India asking why both countries have become increasingly competitive, denoting them as giants on the rise. Communalities as their immense population, economic dynamics, or geography are seductive to pigeonholing both countries and looking at them without sufficiently taking into account the complexity of such a comparison. The apparent differences between both countries and their unique characteristics can teach important lessons though. In addition, discussion is largely focussed on the prognosis of growth rates.

We will thus highlight further important factors that determine the economic performance of China and India and that have only lately entered the discussion on the factors that make a country internationally competitive or not-central traits of its society, cornerstones in history, or its cultural shape. Starting with the discussion why pure economic determinants cannot solely explain a country's competitiveness (Section 2), we will give an overview of the general development of the two countries considered and present common indicators of competitiveness (Section 3). Then, we will analyze previous qualitative research and evaluate quantitative data to assess which country has more favorable socioeconomic factors influencing its economic performance in the long run (Section 4). Finally, the paper offers a tentative prognosis whose socioeconomic determinants are more conducive to long-term economic success. 


\section{Competitiveness and Its Determinants}

In increasingly open and integrated markets, a country's competitiveness is the central prerequisite to succeed on international markets. The common literature provides ample definitions of the term "competitiveness" which concentrate on the macro-, meso- as well as on the microeconomic level. However, in addition, economic performance is to a large extent determined by socioeconomic factors of a society and thus by determinants beyond the economic sphere.

When discussing competitiveness, problems start with trying to define the term. Neither in theory nor in praxis there is a common definition of the term competitiveness. In particular, problems occur when trying to define the notion of competitiveness of a country whereas the definition on a microeconomic basis is widely acknowledged. An enterprise is said to be competitive if it is able to improve the quality of its products above average or to reduce the costs of its production to an extent that it can enlarge market share or profit compared to its competitors. On a national basis, however, competitiveness can not be defined simply in analogy to the microeconomic notion. The distinction then is much more difficult. The OECD defines competitiveness as the extent to which a nation is able to produce goods and services that can be traded on international markets under the conditions of free trade and just market conditions simultaneously to an increase of the real income of the inhabitants (OECD, World Competitiveness Report 1997). The cornerstones free trade, competition, economic growth, and the ability to increase the sales of own products on international markets are also applied by other attempts to define competitiveness [2-4] depending on focus, further aspects of competitiveness are added. Fagerberg [5] sees competitiveness as the ability of a country to realize growth and employment while simultaneously avoiding imbalances in the balance of payments. According to Newall [6], the successful sales of domestic products on national and international markets shall contribute to improve the infrastructure of social services and support the socially weak. A definition which is similar to that of Fagerberg [5] is offered by the Union of Industrial and Employer's Confederations of Europe, which adopts the thought that a high living standard of a country's inhabitants compared to other countries while sustaining the balance of payment is an expression of competitiveness (similarly: His Majesty's Treasury [7]).

Even more difficult than a definition of the term competitiveness is a categorization of the determinants that may explain whether a country is competitive or not. If understood as growth, neoclassical and endogenous growth theory can provide insights into the determinants of competitiveness. Neoclassical growth theory emphasizes the role of accumulation of human and physical capital for the longterm development of an economy. The higher the investment of a region in its stock of capital, the higher the level of regional income per capita. But this impact of investment on growth reaches a border, continuous growth can only be achieved by technological progress. Technological progress, however, is not endogenous in the model (Solow [8]) and has only been included in exogenous growth models, explaining the determinants of technological progress. In most models, technological progress is the result of the private sector's research and development efforts. The wealth of a region is foremost determined by the creation of novel knowledge, which itself depends on innovative activities of enterprises (Romer [9], for an overview: Barro and Sala-i-Martin [10]; Maussner and Klump [11]; Aghion and Howitt [12]). This idea goes back to Schumpeter who considered growth on a microeconomic level and the meaning of enterprises for the growth cycle [13]. But to develop a model of endogenous growth on an aggregate basis, all enterprises need to show identical production functions have the same stock of capital and labor force. That is a strong discrepancy to the proposed recurrence to the assumptions of microeconomic theory that are needed to formulate a theory of endogenous growth [11]. The presentation of entrepreneurial conduct that is conceived to be the determinant of growth thus becomes highly stylized and draws an inappropriate picture of entrepreneurial decision making. Furthermore, growth theory is not a sufficient concept when looking at international trade flows. Most growth models are models of closed economies, immobile factors of production are assumed and the trade of goods and services is widely neglected.

The aspects of trade are the issue of the traditional and the new trade theory. In traditional trade theory, going back to Adam Smith and David Ricardo, countries are equipped with different production factors which are used by trade in the form of comparative advantages. In the framework of international work sharing, nations specialize on products in production, the production of whichhas comparative advantages. Efficiency gains generate higher growth rates. Through international free trade the factor costs for labor and capital adjust and the resources of single countries complement each other [14]. On polypolistic markets, identical investment rates and equal access to technological knowledge assumed for every economy, growth again, according to the neoclassical convergence hypothesis, is determined only by population growth and technological progress. Underdeveloped countries then catch up to developed economies. The traditional model of trade in tradition of Viner, however, suffers from an important short coming: The trade structure of the integration partners is necessarily asymmetric. The results of the analysis are thus dependent on the assumed specific trade pattern [15]. Furthermore, the barriers of neoclassic theory as an explanation for competitiveness may be seen in the fact that in reality, important assumptions are hurt, such as homogenous products, homogenous factors of production, polypolistic markets, or limited capacity of production. Changes in economies of scale and the degree of competition on incomplete markets are neglected. In addition, these models do not offer an explanation why enterprises are able to develop competitive advantages both through trade and foreign investment and why they are able to defend their advantages for long time periods. The new trade theory shows that profits can be gained from trade independently of the existence of comparative advantages. On markets of monopolistic competition or in 
oligopolies, trade liberalization and an extension of domestic markets may lead to a more intensive use of economies of scale and increased competition from the viewpoint of a single enterprise [16]. Increasing economies of scale may lead to a specialization of countries and regions, even if there are no differences in the equipment with resources or technology. Savings and thus competitive advantages then derive internally from the size of an enterprise and externally through the size of a branch or industrial agglomeration. In the latter case, positive externalities lead to further cost reductions and efficiency gains. The new trade theory adds to the neoclassical concept of comparative advantages the aspect of incomplete markets.

However, the determinants of competitiveness in fact lie on the level of entrepreneurial behavior. Schumpeter realized that entrepreneurs create technological and financial progress to survive in a framework of increasing competition and declining profits. Innovation is one main factor of entrepreneurial activity [13]. To analyze why entrepreneurs are innovative, an immensely stylized theoretical framework as in growth and trade theories appears to be insufficient.

Thus, the question has to be changed: the central question is in which surroundings an enterprise can develop innovational potential, which framework does create a fertile ground for competitive action?

Based on this reasoning, the strategic management has contributed largely to the empirical analysis of competitiveness, the most influential impulses coming from Porter. Porter [17] argues that competitiveness is based on the business environment and the sophistication of company operations that are summarized under the aspects of (1) factor endowments, (2) strategy, structure and competition in an industrial sector, (3) demand conditions, and (4) the existence of industrial clusters. Factor endowments include human and physical resources, knowledge, capital, and infrastructure. Regarding demand conditions, the needs on the domestic markets are of special interest. Sophisticated demand structures may induce competitive advantages of some enterprises compared to their competitors. The influence of related and supporting industries can be deduced to continuous improvements of processes and products. Firm strategy, structure, and rivalry are aspects that may constitute advantages of certain branches. Porter takes into account that a favoring macroeconomic situation is a necessary, but not a sufficient condition for growth and prosperity.

This approach has become popular as Porter's Diamond, that aggregated many former ideas on competitiveness. The diamond is based on extensive empirical work, so that the advantages of the approach lie in its great proximity to practice and less in the elegance of modelling. However, from his heuristic approach, it is possible to deduce patterns and regularities [18].

Apart from the overall macroeconomic and political framework and the institutional surroundings, enterprise performance depends on long-term social determinants of a country and thus on primarily noneconomic factors. The concept of systemic competitiveness developed by the German economists Esser et al. [19], hence, includes social aspects. Their approach is based on the assumption that dynamic industrial development is not only based on wellfunctioning markets and the strategies of individual enterprises, but also on common efforts to build up an encouraging framework for the development of the enterprise sector. Micro- and macroeconomic aspects are complemented by the evaluation of meso- and metaconcepts. Specific politics in sectors like technology, industry, regional development as well as the institutional and organizational surroundings supporting the business sector are summarized under the notion of the mesolevel. At the metalevel the capability of actors at the local, regional, national, or even supranational level to create favorable conditions for industrial dynamism is addressed. This includes the social prestige entrepreneurs enjoy in the society, social values favoring change and innovation as well as social capital and social cohesion. Values and norms of a society manifest themselves in social organizational structures and behavioral patterns that can contribute to or harm competitiveness. Thus there is a cultural dimension of economic acting [20, page 3130]. In the following paragraphs, we will analyze these factors in detail and consider "meta"-influences on the competitiveness of China and India.

\section{Jump Start of the Giants}

Today, China and India are outstanding. In fact, China had been outstanding before. In the year $1600 \mathrm{AD}$, the Chinese empire was the greatest and most developed among all unified empires in the world. At the same time, Russia had only started growing together, India was scattered between Mogul and Hindu reign, and the giant empires of Mexico and Peru had fallen [21]. Yet, more recent history did not show such a positive picture, neither for China nor India. Soviet type socialism in China and import substitution policy, banning India in economic backwardness, were yet replaced by opening for foreign direct investment and export-led growth, respectively. These market-oriented reforms allowed for the rise of the Asian giants since the 1980s and shall briefly be summarized.

In the first years of the People's Republic of China, economic development was ambivalent. Between 1952 and 1975 , GDP grew on average by $6.7 \%$ on an annual basis, yet consumption stagnated. Education, social security, and medical care were improved, and the share of industry in total output grew from 20 to approximately $45 \%$. This development was largely based on mobilization of additional human resources while investments in capital stock became more and more inefficient. Only Mao's death in September 1976 and the takeover of Deng Xiaping in 1978 opened a gateway for reforms that were responsible for the economic jump start.

The start of reforms in China is commonly dated the XI Congress of the Communist Party of China in December 1978. Neither precise reforms were concluded nor a time schedule was elaborated, yet there was an ideological change. Deng Xiaping's pragmatism won over Maoist dogmatism of Hua Guofeng; economic development was declared as the primary goal of party policy [22]. After the Cultural 
Revolution, China had fallen behind its Asian neighbors; now, reforms of a gradual and experimental nature were initiated that targeted agriculture, creation of private enterprises, and restructuring of state enterprises and, most importantly the opening of the economy that attracted foreign direct investment and hence facilitated technology transfer [23].

In 1978, China was fairly isolated from East and West and hence one of the least open economies in the world. Foreign trade accounted for only 14\% of GDP in 1978 whereas world average was 34\%. In 1979, however, central government decided to extend foreign trade and allow foreign direct investment. Two provinces were chosen to experiment with these reforms; in 1980, four special economic zones were created-Shenzen, Zuhai, Shantu and Xiamen-that were granted various privileges. For example, projects for foreign direct investments up to USD 30 million could be granted independently. Market institutions and private property were tolerated here [22]. Today, these four regions are gravity centers that bind factors of growth. Positive effects of foreign direct investment can be found here, supported by capitalist local governments that foster market institutions and industrial infrastructure and thus new investments. Whereas in the Eastern Chinese autonomous region Xinjiang or in the Central Chinese province Qinghai, state enterprises are responsible for more than $70 \%$ of industrial production, this share is less than $20 \%$ in Jiangsu, Zhejiang, Fujian or Guangdong (2003) [24].

During the third plenum of the XXIV. party congress in November 1993, the most important decisions were made with regard to a modern system of enterprises. The concept of socialist market economics was filled with a rich reform agenda that became the basis of following reforms [22, 25]. Yet only in September 1997, a real breakthrough with regard to property rights was achieved during the XXV. party congress, when private property was declared an important component of economy while state ownership was reduced from a major part of economy to one pillar of economy. In March 1999, private property as an important component of socialist market economy was included in the Chinese constitution [23]. The reform process was finally crowned with WTO accession in 2001.

In India, average annual growth between 1950 and 1980 was only $3.7 \%$. Poverty and social inequality as well as the lack of education were not overcome. In the era of Indira Gandhi (1966-1977), encompassing regulation (licence raj) was created and huge parts of the financial sector and external trade were nationalized. When she tried to nationalize the essential trade of grains, the climax of Indian isolation was reached. It was her son Rajiv Gandhi that initiated deregulation and liberalization [26]. Even though these reforms were hesitant, his reign was the start for improving development.

First steps of liberalization were made since 1980 and accelerated in 1985, even though they lacked stringency and received little attention. Imports, especially imports of machinery and raw materials that were not produced in India, were more and more liberalized. Incentives to export have been created especially since 1985 . With regard to the

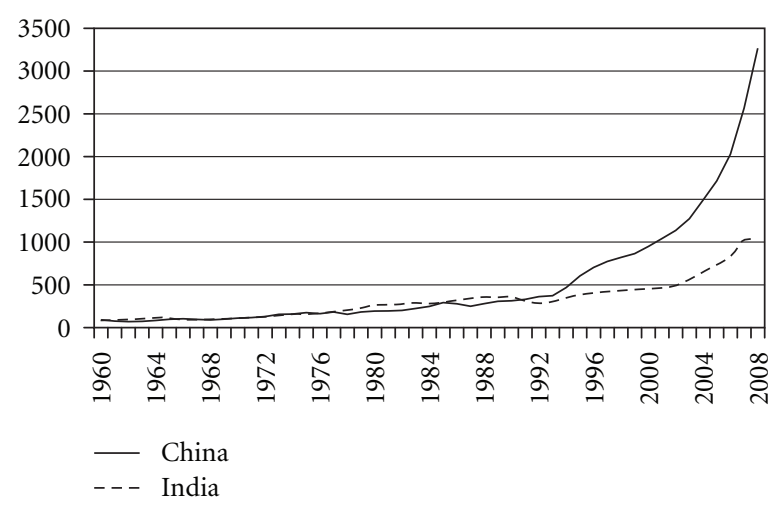

FIGURE 1: GDP per capita (in current USD). Source: own presentation based on World Bank data.

domestic market, the number of industries working under governmental license was reduced by 31 sectors, even though important branches such as steel, coal, textiles, and chemicals remained under governmental control. Nevertheless, huge enterprises were usually subject to many restrictions and could not benefit from these measures of liberalization. Yet, the threshold for being a huge enterprise was lowered, so that approximately half of all huge enterprises were no longer classified as such. Devaluation of the rupee contributed to high exports during the late 1980s [27]. As a summary, those reforms have facilitated access to foreign technologies and capital goods, strengthened competition and enlarged the possibilities for entrepreneurial actions. The fact that relatively small internationally merely recognized reforms have had such an effect has been explained by Rodrik and Subramanian [28], or DeLong [26] with the help of the conducive institutional, political, and cultural environment. As a country with such relatively good political and economic institutions, a more or less working legal system, cultural values oriented on education, and democratic constitution, India was far below its longterm growth potential in 1980. Hence, small steps could have great consequences. Yet, regional inequality remained enormous, and the industrial sector was lagging behind significantly, having negative effects on aggregated growth. After all, first steps of deregulation and liberalization were tentative. It was only after the breakdown of communism in Eastern Europe and a heavy crisis rooted in the balance of payments that an encompassing reform program was initiated. Ever since, market principles are introduced on a wider scale, even though implementation tends to be slow [29].

Since 1978, China has experienced enviable growth, as Figure 1 shows. For the future, researchers expect that the real growth rates of India and China will approximate. In their study that has become famous under the name BRIC study, Wilson and Purushothaman [1] forecast continually higher growth rates in India than for China starting in 2013. Yet, per capita GDP will grow much faster in China given the Indian demographic development. 


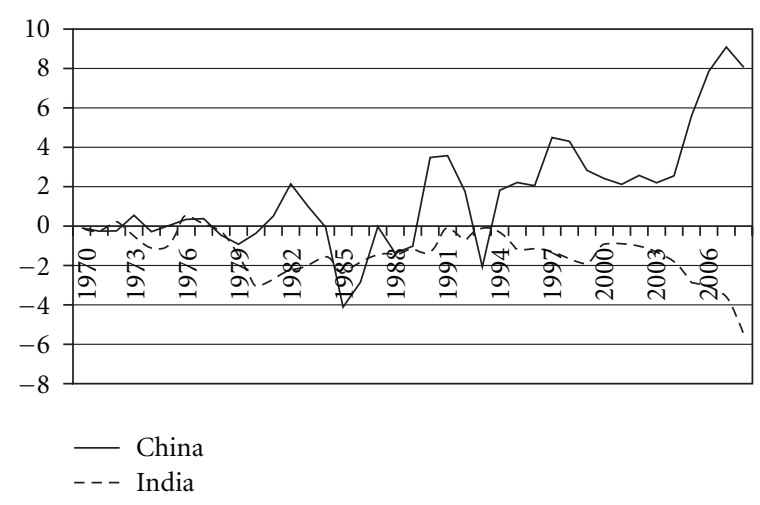

Figure 2: Trade balance (in percent of GDP). Source: own presentation based on World Bank data.

In its most recent ranking for 2009-2010, the Global Competitiveness Index ranks China as the highest among those for future economic giants, 20 places ahead of India and even more of Brazil and Russia. GDP growth has taken an impressive average of 9.8 and $6.2 \%$, respectively, yet, GDP per capita remains modest (Table 1).

Yet, it is not to be denied that some problems China and especially India face remain severe. Whereas $42 \%$ of the Indians still lived below the extreme poverty line of USD 1.25 a day in 2005 compared to $54 \%$ in 1988 , extreme poverty in China has been reduced from 54 to $16 \%$ in the same period. Life expectancy is lower and infant mortality higher in India than in China, and also in purely economic terms, the gap remains large. FDI into India in 2007 was a quarter of the inflows into China; China's exports are more than India's overall GDP [30]. Figure 2, presenting the trade balance, backs this assumption.

Often, analysis is focussed on forecasting growth rates that are per se not sufficient for evaluating a country's competitiveness. Nevertheless, comparisons in the literature are abundant; both countries are praised as future giants of world economy and mentioned as a couple. Bloom et al. [31] and Bosworth and Susan [32], Bronger and Wamser [33], Chai and Roy [34], Das [35], Desai [36], Fromlet [37], Gilley [38], Khanna and Huang [39], Long [40], Panagariya [41], or the edition by Winters and Yusuf [42] compare reforms, overall development, and growth, to name just a few of the more recent publications. Table 2 gives an overview on respective determinants of competitiveness while citing exemplary sources.

One determinant - and only one among many othersfor future competitiveness is socioeconomic characteristics of both countries. The short summary above has shown that economic reforms were able to induce a process of astonishing growth and catching up; yet they relied on the respective cultural framework.

With regard to Eastern European transition countries, Brockmeier [43] has noted that economists especially at the beginning of transition obviously expected something like a microeconomic automatism of adjustment, resulting in a lack of literature on the microeconomics of transition. They expected enterprises and households to do what was needed, but neglected that new formal institutions have to fit to culture, moral, and norms - that is, the informal institutions of a society. Formal institutions need a moral foundation. Consequently, formal rules, especially the laws, need to fit to informal, primarily culturally shaped, rules. Brockmeier [43] thus concludes that there would always be tensions when formal rules were changed suddenly and did not fit to the old actors and their convictions, values, or habits that have developed in the long term.

Thus, a functioning economic order cannot simply be prescribed. People have to get acquainted with new formal institutions to learn how to deal with them. This process will take a lot of time and will only work out if there is at least a small intersection with old informal institutions. China and India share a lot of such informal institutions that are conducive to market economy, as the following discussion will show. Hence, socioeconomic determinants are one piece in the puzzle that gives the full picture of their competitiveness.

\section{Socioeconomic Determinants of Competitiveness}

Max Weber in his 1904 classical treatise "The Protestant Ethic and the Spirit of Capitalism" was the first to investigate the relation between culture and economic development. Weber argued that Calvinist doctrine of human predestination demanding commitment to work and social dedication and at the same time applying economic success as the benchmark of divine mercy fostered economic development. In his later work, Weber postulated a negative connection between Asian Confucianism and the development of capitalist economic structures [20, page 3131].

In more recent past foremost, new institutional economics picked up this approach and acknowledged the relevance of informal path-dependent social systems of rules and norms for a successful industrial development (esp. [44, $45]$ ). In contrast, other economic schools of thought neglect the influence of social values on economic performance. Neoclassical theory assumes that economic actors behave rationally and maximize profits. However, vast empirical studies prove that mostly this is not the case, and also that cultural factors can result in different economic behavior. The reason why cultural factors nevertheless only rarely form part of economic models is due to problems of measurability. Cultural factors are not easily separated from other determinants, so that the exact fraction of economic performance that is owed to sociological elements can hardly be determined (Camerer [46], esp. chapter 2).

The following paragraphs will compare and evaluate the manifestation of cultural values and norms in China and India. By focussing on the development of social capital and the analysis of the political-economic orientation, two especially influential sociological factors will be analyzed. The results will be used to derive implications for the international long-term competitiveness of both countries. 
TABLE 1: Selected Indicators for the BRIC Countries.

\begin{tabular}{lccccc}
\hline & GCI & $\begin{array}{c}\text { GDP (USD billion) }{ }^{\mathrm{a}}, \\
\text { rank } \\
\text { (out of 133) }\end{array}$ & $\begin{array}{c}\text { GDP per capita in } \\
\text { USD }\end{array}$ & GDP CAGR (\%), & \multicolumn{2}{c}{ Population (millions) } \\
& $2009-2010$ & 4,327 & $(2008)$ & $1991-2008^{\mathrm{b}}$ & 2008 \\
\hline China & 29 & 1,207 & 3,259 & 9.8 & 1,336 \\
India & 49 & 1,573 & 1,017 & 6.2 & 1,186 \\
Brazil & 56 & 1,677 & 8,295 & 2.9 & 1,658 \\
Russia & 63 & 11,807 & 1.9 & 194 \\
\hline
\end{tabular}

Source: Geiger and Rao [30, page 6]. Sources of Data: IMF, UNFPA, World Economic Forum.

${ }^{a}$ Current prices.

b 1992-2008 for Russia.

4.1. Norms and Values. Culture is a system of basic common norms and values, informal institutions, cognitive schemes, and daily activities, that altogether coin human behavior within a society [20, page 3130]. Such defined culture develops through historical and religious influences and the daily interaction within a society. Cultural factors are thus a dynamic variable that continues changing over time. This process however develops slowly, so that cultural manifestations have long-term meaning.

Chai and Roy [34] argue that China's cultural heritage tends to favor modern economic development more than does India's. The values of Chinese Confucianism emphasize the importance of education, integrity, assiduousness, and mutuality-virtues conducive to economic development.

Indian Hinduism, in contrast, claiming divine salvation by asceticism, promotes individualism and undermines the yearning for material wealth and economic success as well as the accumulation of savings. The abjuration of all earthly wealth that was claimed by Ghandi as well does not favor economic progress. In addition, obvious strengths of Hinduism such as tolerance and diversity seem to convert themselves into weaknesses such as a lack of organization and assertiveness [48, page 31 ].

In addition, the caste system, though officially abolished by constitutional decision in 1949, but still present in everyday life, influences economic activity negatively since it limits the freedom to choose a profession and the chances of cooperative behavior and sets negative incentives, given the impossibility of social advancement (Chai and Roy [34, page 8ff]; Ihalu [48, page 48]). However, there are signs that the rigid social system slowly softens: Wiproboss Azim Premji is Muslim, Narayana Murthy, and chief of the second largest Indian software enterprise Infosys Technologies, comes from a lower caste. Competition and a new ethic in the multicultural metropolis Bangalore that is captured by a secular spirit more than other urban centres repel religious identity and stress economic success. However, this may not belie the fact that the Brahmans still dominate key positions in the Indian knowledge society [48, pages 15 and 18].

Both countries share reluctance concerning external influences rooting in historical experiences of foreign occupation. In India, this assumes such proportions that branches of the US-American fast food chain Kentucky Fried Chicken are perceived as a national danger [59, page 28]. Even after independence, this attitude manifested itself in a farreaching isolation from the global market. Paired with desolate infrastructure, this is one factor accounting for the comparatively low level of foreign direct investment.

Yet English imperialism also bequeathed a working administrative system, democratic structures and modern institutions. An efficient legal system that guarantees the implementation of laws and property rights exists.

Historical and religious characteristics that form a country's culture influence social attitude towards work, technological progress and education and thus economic development. We will therefore analyze respective questions from the most present World Values Survey (2001) and evaluate the answers for both China and India.

The World Values Survey is the most encompassing globally-conducted survey on socio-cultural, moral, religious, and political convictions. The poll is realized by an international network of social scientists of leading universities; the results are freely accessible on the organization's website. In each country, questionnaires are filled in within personal interviews. The questionnaire of the last survey is formed by about 250 questions. In 2001, 1,000 people were interviewed in China and 2,002 people in India. The key sociodemographic figures of the interviewees are summarized in Table 3.

4.1.1. Attitude Towards Work. In the survey, the attitude towards work is sampled by the means the following of four questions:

(1) is work important in life?

(2) does work make life worth living?

(3) is one obliged to work towards society?

(4) should the meaning of hard work be conveyed to children?

Figure 3 underlines that work plays an important and generally accepted role in both India and China. This ethics contributes to national competitiveness. Partly, a correlation between the appreciation of work and the level of education can be identified.

4.1.2. Attitude Towards Technology and Progress. The question whether technological progress should receive more 
TABle 2: Determinants of competitiveness compared.

\begin{tabular}{|c|c|c|}
\hline & China & India \\
\hline \multicolumn{3}{|c|}{ Macrolevel } \\
\hline \multirow{3}{*}{ Politics } & $\begin{array}{l}\text { + relative political stability due to improving } \\
\text { living standards [47] }\end{array}$ & $\begin{array}{l}\text { - variety of religions, ethnicities, and languages; } \\
\text { rigid caste system [48] }\end{array}$ \\
\hline & $\begin{array}{l}\text { - potential of social disruptions given the } \\
\text { Communist Party's monopoly of power [29] }\end{array}$ & - tensions with Pakistan [49] \\
\hline & - neglection of human rights [37] & $\begin{array}{l}\text { - frequent changes of government and minority } \\
\text { governments }[50]\end{array}$ \\
\hline \multirow{3}{*}{ Demographics } & $\begin{array}{l}\text { + population growth allows for extensive growth } \\
\text { [31] }\end{array}$ & $\begin{array}{l}\text { + population growth allows for extensive growth } \\
\text { [31] }\end{array}$ \\
\hline & $\begin{array}{l}\text { - population growth likely to have negative } \\
\text { impact on p.c. GDP [51] }\end{array}$ & $\begin{array}{l}\text { - population growth likely to have negative } \\
\text { impact on p.c. GDP [51] }\end{array}$ \\
\hline & $\begin{array}{l}\text { - aging population challenges social security } \\
\text { system [52] }\end{array}$ & $\begin{array}{l}+ \text { young people allow for intensive growth if } \\
\text { education is supported [53] }\end{array}$ \\
\hline \multirow{3}{*}{ Labor market } & $\begin{array}{l}\text { unemployment rate of } 4.2 \% \text { in } 2008 \text { (World } \\
\text { Bank) }\end{array}$ & $\begin{array}{l}\text { unemployment rate of 5.0\% in } 2004 \text { (World } \\
\text { Bank) }\end{array}$ \\
\hline & - pressure on labor markets is rising [54] & $\begin{array}{l}\text { - employment in public sector has fallen and was } \\
\text { not backed by increases in private economy [34] }\end{array}$ \\
\hline & & $\begin{array}{l}\text { - quota regulations for scheduled castes have led } \\
\text { to demoralization and unsatisfactory } \\
\text { performance in public sector }[48,55]\end{array}$ \\
\hline \multirow{2}{*}{ Fiscal and monetary policy } & + relatively low debt and deficit [56] & - expansive fiscal policy [57] \\
\hline & $\begin{array}{l}\text { - fixed exchange rate regime, requiring capital } \\
\text { controls [58] }\end{array}$ & + restrictive monetary policy [57] \\
\hline \multirow{2}{*}{ External relations } & + huge FDI inflows & \\
\hline & + trade balance surplus & - trade balance deficit \\
\hline \multicolumn{3}{|c|}{ Meso- and microlevel } \\
\hline Industrial structure & $\begin{array}{l}\text { + China as the global workbench, including high } \\
\text { share of high-technology exports ( } 29 \% \text { in 2008; } \\
\text { World Bank) }\end{array}$ & - high dependence on services sector [41] \\
\hline Business environment & $\begin{array}{l}\text { Doing business ranking } 89 \text { of } 183 \text { in } 2010 \text { (World } \\
\text { Bank) }\end{array}$ & $\begin{array}{l}\text { Doing business ranking } 133 \text { of } 183 \text { in } 2010 \\
\text { (World Bank) }\end{array}$ \\
\hline Entrepreneurship & $\begin{array}{l}\text { + large share of high-growth expectation } \\
\text { early-stage entrepreneurship (Global } \\
\text { Entrepreneurship Monitor) }\end{array}$ & $\begin{array}{l}\text { - small share of high-growth expectation } \\
\text { early-stage entrepreneurship (Global } \\
\text { Entrepreneurship Monitor) }\end{array}$ \\
\hline Education & $\begin{array}{l}\text { + high priority on education, consistent programs } \\
\text { [29] }\end{array}$ & $\begin{array}{l}\text { - still, securing primary education is main task } \\
\text { [29] }\end{array}$ \\
\hline
\end{tabular}

Source: Own presentation.

TABLE 3: Sociodemographic features of the interviewees.

\begin{tabular}{lcc}
\hline & China & India \\
\hline Number of interviewees & 1000 & 2002 \\
of which male & $49.4 \%$ & $56.8 \%$ \\
average date of birth & 1960.72 & 1953.91 \\
\hline Higher education (in \%) & 4.3 & 23.3 \\
Intermediate education (in \%) & 53.9 & 24.3 \\
Lower education (in \%) & 41.8 & 51.9 \\
\hline High household income (in \%) & 23.4 \\
Intermediate household income (in \%) & 34.5 & 40.9 \\
Low household income (in \%) & 37.5 & 37.4 \\
\hline
\end{tabular}

Source: own presentation based on World Values Survey 2001. 


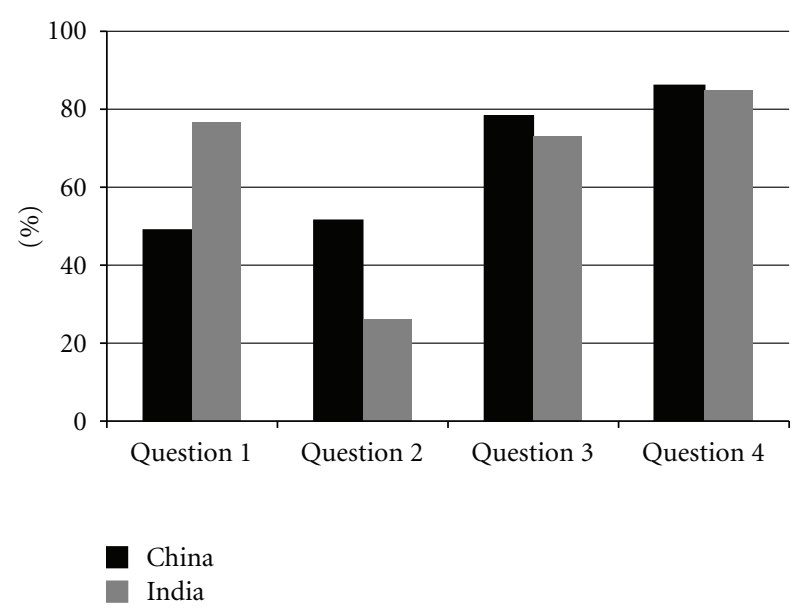

Figure 3: Attitude towards work in China and India (approval in percent). Source: own presentation based on World Values Survey 2001.

attention was answered with "yes" by $96.7 \%$ of the Chinese but only $56.7 \%$ of the interviewees from India. In addition, the attitude towards technology and progress in India is highly correlated with the educational background. Only $44 \%$ of all respondents with lower education, but $80 \%$ of those who had higher education acknowledge the importance of technological progress.

Likewise, scientific progress receives higher valuation in China; nearly $80 \%$ of all interviewees think it helpful. Interestingly, especially those interviewees with lower education share this opinion. Only $60 \%$ of all Indian interviewees evaluated scientific progress as helpful for the overall development while $17.3 \%$ assumed harmful influences.

4.1.3. Education. The World Values Survey does not poll the attitude towards education. Delong [26], however, recognizes a high standing of education and knowledge within the Indian society, which he identifies as a significant competitive advantage. Brahman ditties which had been relayed for over thousand years before they were finally written down have been preserved especially in the South and procured a strong mathematical tradition, supporting analytical thinking and the present focus on natural sciences and technological innovations [48, page 19]. Another plus factor that has its roots in historical and cultural development is the wide coverage of the English language. In times of globalization and economic integration, this is a significant advantage of location [26, page 19].

Chinese culture as well attaches great importance to education. Confucianism with its inherent appraisal for education and knowledge is deeply routed in Chinese society and manifests itself in high motivation shown by Chinese pupils and students [4, page 15]. The multitude of Chinese students at universities abroad underline this fact.

Being compared, historical and religious influences on Chinese and Indian culture may suggest a social attitude more beneficial to economic development in China. The analysis of attitude towards work, technology, and education however, backs this assumption only partly. Only the more positive attitude towards technology and progress favors China. India, in contrast, profits from more Western mentality, left behind by British imperialism, its institutional heritage, and the wide distribution of English as lingua franca.

4.2. Social Capital and Social Networks. A society's social capital is as well a source of economic development and prosperity as human or physical capital. Social capital is productive in the sense that it opens up opportunities that otherwise could not be realized or only at much higher cost.

Whereas human capital denotes the individual capabilities of single members of a society, social capital is the structure of social linkages within a society [60, page 98]. Social contacts facilitate cooperative behavior that benefits all participants. According to Putnam [61], social capital is those characteristics of social organizations that support coordination and cooperation within a society. Trust, networks, and social norms constitute themselves as the parameters of social capital [61, page 67].

In scientific literature, two types of trust are distinguished: Interpersonal trust is the trust between individuals whereas systemic trust means confidence in the political, economic, and institutional system [62, page 42]. When economic actors lack trust into the system, they will not use it but act on the black market. In contrast, systemic trust promotes political participation and can foster the quality of economic decisions and investments [63, page 1252f].

Interpersonal trust reduces the necessity of sophisticated contracts and trials and thus reduces transaction costs, while simultaneously increasing the propensity to take entrepreneurial risk. This is especially crucial for small and medium-sized enterprises that are more exposed to risk by nature but play a significant role for national competitiveness. Interpersonal trust raises horizontal and vertical links between enterprises and alleviates the emergence of industrial clusters.

Knack and Keefer [63] explored the relationship between interpersonal trust, civic cooperation, including levels of associational activity and formal institutions, and economic performance. They found that trust, and norms of civic cooperation tended to be stronger in countries with formal institutions effectively protecting property and contract rights, as well as in countries that were less polarized along lines of class or ethnicity. The key finding is that trust and civic cooperation are associated with stronger economic performance; contrarily to Putnam [64] who found associational activity and economic performance not to be correlated. The trust indicator and the indicator for the strength of norms of civic cooperations were taken from the World Values Survey in 1981 and 1990-91 and included 29 market economies. Knack and Keefer [63] test the impact of trust and civic norms on both growth and investment rates; other explanatory variables included are the proportion of eligible students enrolled in secondary and primary schools in 1960, per capita income at the beginning of the period, and the price level of investment goods relative to the USA. 
Using average annual growth in per capita income over the 1980-92 period, the social capital variables exhibit a strong and significant relationship to growth [63, pages 1260-1]. Varying their estimation, Knack and Keefer [63] support the assumption that trust is more essential in poorer countries where contracts are not reliably enforced by the legal system and where access to formal sources of credit is more limited due to an underdeveloped financial sector. Also, instrumenting for trust to correct endogeneity problems or possible measurement errors, the trust indicator remains statistically significant.

Trust is thus the fundament of social capital and has an outstanding importance for economic development: "Virtually every commercial transaction has within itself an element of trust, certainly any transaction conducted over a period of time. It can be plausibly argued that much of the economic backwardness in the world can be explained by the lack of mutual confidence" [65].

Whereas sociologists are mainly interested in how social networks produce or inhibit trust, economists emphasize trust as a way of reducing transaction costs and its role as a lubricant of the economy. In any economic contract, there needs to be a productivity advantage or norm assuring traders that the other side will hold up its end to the deal. Legal contracts, third-party assurance, family solidarity, or credible threats of violence may provide such assurance albeit being costly; trust is cheap.

Especially trust-sensitive transactions include those in which goods and services are provided in exchange for future payment, employment contracts comprising tasks of the employee that are hard to monitor, or investment or saving decisions relying on assurances by banks or government that they will not expropriate the assets [63, page 1252].

Thus, high-trust societies provide a framework in which individuals need to spend less to protect themselves from being exploited, where written contracts are less likely to be needed and thus do not have to specify every possible contingency, and where litigation may be less frequent; efforts to protect oneself from unlawful violations of property rights can be reduced. In addition, high levels of trust can substitute for formal institutions. As government officials may be conceived as more trustworthy in high-trust societies, policy pronouncement may appear more credible and thus foster investment and economic activity [63].

In addition to the direct effects of trust on economic activity, there may as well be indirect improvements through political channels. Both trust and civic norms can improve governmental performance and the quality of economic policy as they affect the level and character of political participation. Large-scale participation and profound knowledge of politics by a large number of citizens both enrich politicians and bureaucrats and narrow interests they are allied with [63].

In contrast, low-trust environments discourage innovation as more time is needed to monitor potential malfeasance by business partners or employees, time that could otherwise have been spent on innovation efforts. Hiring decisions are influenced by personal attributes of applicants as blood ties or personal knowledge more than by educational credentials.
In turn, the returns to acquisition of educational credentials are reduced and thus the incentives to their acquisition [63].

Similarly, norms of civic cooperation can be linked with economic outcomes. Such norms act as constraints on narrow self-interest and thus create incentives to contribute to the provision of public goods of various kinds. Technically speaking, internal as well as external sanctions-guilt, shame, ostracism, and so forth-associated with norms alter costs and benefits of cooperating and defecting in prisoner's dilemmas [66].

Social networks fasten information flows within a society, enhance trust, and promote cooperative behavior. To conclude, positive forms of social capital help make economic processes more efficient, so there is a positive correlation between social capital and growth. Raiser [67] as well as Putnam [64] find a positive correlation between both trust and growth and social activity and growth. It is interesting in this context that the connection between social capital and economic development is by no means one dimensional: social capital fosters development, but economic development also supports social capital. A competitive market economy is the best framework to limit the role of nepotistic networks [68, page 3]. In addition, a vital market economy with osmotic social groups whose members and compositions change, where there is a high degree of private, social, political, economic, and regional mobility, makes initially completely strange people cooperate and communicate. The disruption of traditional structures and linkages in modern market economies brings about exactly those interests and values-trust and reciprocity-that are desirable from an economic point of view and also politically, as they are required for a functioning democracy [69, page 39], what is especially relevant when looking at China.

Huntington [70] underlines that there cannot be an argument about the fact that traditional Confucianism is un- or even antidemocratic [70, page 15]. As in other less democratic cultures, "Confucianism merged society and the state and provided no legitimacy for autonomous social institutions at the national level" [71, page 301]. Yet, the situation has changed in reaction to the enormous economic progress, which may be a proof for the fact that economic change may help overcome autocratic structures [68, page 6f]. Informal networks between political and economic actors, however, persist and do not contribute to democratization [47, page 195]. The chances of democracy are greatest where the links between politics and economics are limited and segmented [68, page 4].

India as a Hinduist country in contrast kept its cultural identity throughout history without being bound to a political framework; here, politics was always practised in secular forms [72, page 32]. In addition, Hinduism is a pluralistic religion with an immanent respect for diversity $[69$, page 68$]-$ a condition for the stability of the world's biggest democracy. Furthermore, the caste means protection and safety for every individual, social, as well as economic security, a common representation of interests and often a professional monopoly [48, page 49]. Yet, the Hinduist caste system is a severe challenge for the accumulation of caste-crossing social capital, universal trust and common 
values, as the following paragraphs will show. Neither widespread solidarity, sympathy, nor common sense belong to the cardinal virtues of Hinduism [48, page 49].

For analysis, we again utilize different categories from the World Values Survey 2001. We will use the question whether most people can be trusted as an indicator for interpersonal trust; questions on satisfaction with and trust in politics and institutions will measure systemic trust. In addition, corruption will be used as an indirect negative indicator for interpersonal trust. Membership in associations is used as a proxy for the intensity of cooperation and networks.

4.2.1. Trust. Whereas $54.5 \%$ of all Chinese interviewees trust most people, only $41 \%$ of the Indians believe that most people can be trusted. In particular, interpersonal trust decreases with rising education in India whereas higher education is linked to higher levels of trust in China.

4.2.2. Confidence. The following questions were included in our analysis: satisfaction with the government and the degree of democracy, trust in the government, parliament, political parties, public administration, labor unions, the media, and police.

In China, $72.9 \%$ of the interviewees are more or less content with governmental work, compared to $59.7 \%$ in India. Differences with regard to the satisfaction with the state of democratic development are more pronounced. Surprisingly, almost $90 \%$ of the Chinese were satisfied with the degree of democratization, but only $63.4 \%$ of the interviewed Indians. Also with regard to the mentioned institutions, the polled Chinese demonstrate higher levels of trust. Especially striking is that almost none of the Chinese is completely dissatisfied with the state of politics or has no trust at all in the different institutions. In India, however, the share of this group is above $10 \%$ in all categories and reaches a maximum of $28 \%$ when asked on trust in political parties.

4.2.3. Corruption. The question, whether corruption can be justified, is answered with never by $83.5 \%$ of the Chinese and $85 \%$ of the Indians. Yet, $6.5 \%$ of the Indians think corruption is always justified whereas only $0.2 \%$ of the Chinese were of the same opinion.

4.2.4. Membership in Voluntary Associations. The World Values Survey covers the question on membership in one of 14 distinct organizations, ranging from religious communities to educational institutions or sport clubs. In both countries, the degree of participation is relatively low. Yet, the share of members in India of $8.4 \%$ is still significantly higher than in China, where it reaches only $2.7 \%$ on average. In both countries, education highly influences the likeliness to be member of an association (Figure 4). Thus, on average, 9.8\% of the interviewed Chinese and $12.1 \%$ of the Indians that had enjoyed higher education are member in a voluntary organization, compared to only $0.8 \%$ or $6.7 \%$, respectively, of those with lower education.

These results that mirror a higher degree of interpersonal and systemic trust in China but also more cooperation

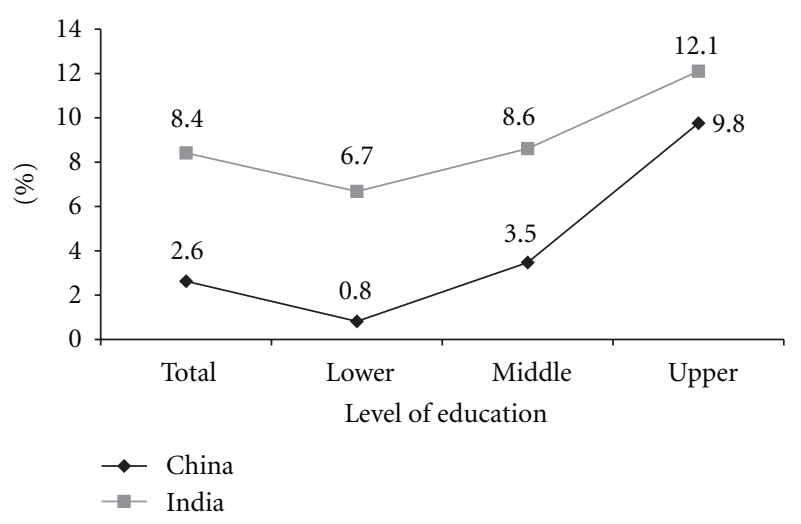

Figure 4: Membership in voluntary associations (according to degree of education, in percent). Source: own presentation based on World Values Survey 2001.

and networking in India can be explained and qualified by historical and social developments.

India is a pluralist multiethnical state with a huge religious, lingual and social diversity. This constellation complicates the emergence of trust and across-the-board networks. Thus, Knack and Keefer [63] find a negative interdependence between social capital on the one hand and polarization of a country according to ethnic groups on the other hand, which is significant in India. The caste system with more than thousand undercastes and at least 20 castes per municipality on average and growing Hindunationalism impede across-the-board integration. Additionally, local disruption of single groups aggravates the creation of links and networks.

Bronger and Wamser [33] identify the multitude of languages as the factor most impedimental to integration in India. Besides Hindi and English as national languages, there are further 21 acknowledged tongues. Less than $40 \%$ of the Indian population speak Hindi, illustrating why English has stayed the common language of economics, culture, and administration until today [33, page 20].

Vanneman et al. [73] analyzed social capital in India based on a country-wide poll of 40.000 households. They used the number of contacts with health, educational, and governmental organizations as an indicator for the existence of social networks. Results reveal a huge degree of variation in social capital according to caste and religion, identifying a rising number of contacts with increasing hierarchy. However, the variation almost completely vanishes when allowed for educational and income differences [73, page $2 \mathrm{ff}]$.

Social networks in India are limited to close circles. Tharoor [59] describes the family as the elementary social unity of India where the notion family is widely defined and can also include a caste grouping or a rural unity. He makes clear that only few Indians have a sense of community that goes beyond ties of blood, caste, or village, which is also expressed in lacking civil culture.

Such tight radii of trust in which group members feel only bound towards each other and to which outsiders have 
no access hinder widely-stretched networks and aggravate the emergence of civil society and working institutions. Fukuyama [74] recognizes negative externalities of social capital here [74, page 8ff].

In China, Han-Chinese are the state-carrying element with a share of population of over $90 \%$. In addition, there is a uniform spoken and literary language, and Confucianism dominates spiritual life, even though the states pursue an atheist ideology [36, page 5].

In spite of the more homogenous preconditions, radii of trust are also limited in China, and social networks are often limited to the family and guanxi-a close network of personal relationships between single people, but not between groups and/or institutions [75, page $4 \mathrm{ff}]$. In addition, the literature sees a negative interdependence between social capital on the one hand and weak formal institutions such as property rights or authoritarian policies on the other hand $[63,76]$.

Vertical command structures are supposed to promote social capital in China, but only voluntary social activity can be a basis for sustainable social capital. Although there is a rising number of nongovernmental organizations, they are controlled by the state and cannot develop freely and generate their full social utility [77, page $7 \mathrm{f}]$. Consequences of the one-child-doctrine hover above Chinese development like the sword of Damocles. A rising number of egocentric single children contradicts traditional Chinese communal values. Scharping [52] thus warns that the Chinese people must envision a dramatically decreasing social cohesion [52, page 70].

As a conclusion, both China's and India's economic development is aggravated by a lack of social capital. Social networks are characterized by tight radii of trust that do not go beyond family and friends. This is fertile ground for corruption but forecloses across-the-board cooperation and thus creates negative externalities. In India, this is owed to the pluralist social structure. A lack of confidence in the system is a further problem that is underlined by the importance of the informal sector. In China, the emergence of social capital is hindered by authoritarian politics and a lack of formal institutions. The state interferes in social processes instead of promoting trust and cooperation through greater passivity. The emergence of social capital can only partly be supported by the state through the creation of formal institutions. Yet, he can exert negative influence by means of its actions.

India's democracy and formal institutions mean a huge competitive advantage, but heterogenous social structures manifest a nearly unsolvable problem with regard to the creation of social capital. China, in contrast, has the opportunity to support the emergence of additional positive forms of social capital - but the state must yield control and increase the civil freedoms of its people.

4.3. Organizational Structure and Economic Concept. A common economic concept is important for a country's longterm competitiveness since it is the only way to create a successful interplay of all spheres of life. It alleviates continuous implementation of collective policies with regard to time and contents as well as enforcement of long-term interests and the creation of stable expectations. In particular, globalization and competition have to be generally accepted.

In the following paragraphs, we will analyze the respective key features in India and China.

4.3.1. Attitude Towards Globalization and Competition. In 2006, the Chicago Council of International Affairs in cooperation with Asia Society, the East Asia Institute and the Lowy Institute conducted a survey in five countries among which were China and India that asked how ongoing globalization is judged by society. Whereas $87 \%$ of the Chinese evaluate globalization as predominantly positive, only $54 \%$ of the Indian respondents are of the same opinion [78, page 71].

Concerning competition, the poll of the World Values Survey yielded the following picture: $90.4 \%$ of the Chinese and $85.7 \%$ of the Indians evaluate competition as predominantly advantageous. In India, the picture is yet more mixed. The survey allows for answers on a scale from 1 to 10 , with 1 illustrating an absolutely positive attitude towards competition and 10 an absolutely negative evaluation. 55\% of the Indian interviewees judge competition with a 1 , but another $10 \%$ with a 10 . In China, absolute agreement was only at $38.3 \%$, but also only $2.6 \%$ judged competition as completely negative.

4.3.2. Interest in Politics and Agreement on Political Goals. The World Values Survey 2001 documents a greater interest in politics in China. More than $70 \%$ of the interviewed Chinese show political interest, in contrast to $45 \%$ of the Indians.

The majority of Indians (54.1\%) think high economic growth rates should be the central political goal. Only $40 \%$ of the Chinese share this opinion, further $40 \%$ see the primary goal in boosting national armed forces. In both countries, the focus on economics is the more likely the higher the degree of education.

4.3.3. Long-Term Orientation. Cultural scientist Geert Hofstede has developed an index of five cultural dimensions that tries to map the dependence between national culture and corporate culture. The index is based on a survey of more than 100.000 IBM employees from 50 countries. One dimension is the long-term societal orientation. China reaches 118 of 125 potential points, India scores only 61 . (Other dimensions are the indicators: distance to power (How big is the respect towards authorities?), individualism, masculinity and risk affinity. The study is mainly criticized for the fact that the sample is not representative. A detailled description of the concept and the single dimensions can be found at G. Hofstede and G. J. Hofstede [79]). However, the methodology of the poll was developed by Chinese scientists and is based on Confucianist values; a systematic bias in favor of China is inherent in the index. Yet, this alone can not explain the huge difference between the Chinese and Indian scores. The higher propensity to save in China (50\% compared to $32 \%$ in India.) (Data for 2005, gross values in percent of national income. Source: World Development 
Indicators Database, World Bank.) can be taken as another indicator for the more pronounced long-term orientation in China.

The studies point towards a higher acceptance of competition and globalization and towards higher interest in politics in China. On the other side, Indians are more likely to agree on primary political goals and put a larger focus on economic development. However, the Chinese tend to develop long-term perspectives which favor the creation of common future visions.

For the development of a common national vision, both the political and social structure of a society are crucial. In contrast to China, India has at no point in history been a unified country under unified leadership. Desai [36] thus concludes that India struggled to articulate a national vision whereas the same was self-evident for China [36, page 5].

Whereas social structure has been analyzed in the preceding paragraph, we now will have a look at the political structure and its influence on the development of a common economic concept. In China, political structure is hierarchical, the Communist Party standing at the top of the pyramid. India is a parliamentary democracy with strong federalist structures. Thus, it is obvious that it is easier for China to pursue long-term political goals than for India where 12 parties form the governing coalition and next elections could bring about a government with completely different economic and political targets. Yet, the question remains in how far a policy that is imposed by one party can be considered as concerted.

It can be stated that it will always be easier for China to articulate long-term goals. However, when the discrepancies between the goals proclaimed by the Communist Party and the opinion of economic actors become too huge, economic slowdown may follow. In addition, economic development challenges the stability of the authoritarian political system. Even Schumpeter [80] argued that modern democracy is a product of capitalist processes.

Modernization forces China into a balancing act between economic self-determination and political heteronomy; we can only wait whether the impressive growth rates may foster democratization or stabilize communist power. Concentration of resources of power on a very small share of the population dilutes the hope for rapid democratization [81]. This concentration of power also limits the role of the newly developing Chinese middle class that could be the carrier of pluralism, liberalization, and thus democratization due to its level of income, education and information [47, page 195]).

India profits from the fact that economic aims are decided upon within democratic processes. Yet, pluralistic structures, federal orientation, and often marginal political majorities endanger a collective and continuous long-term economic orientation.

\section{Concluding Remarks}

China and India are two rapidly growing economies, similarly fascinating economists, politicians, and the general public. The dynamic development of the two giants not only forces established economies to adapt their economic framework to the newly emerging competitive environment but also encourages other emerging nations to study and imitate the underlying patterns of success.

This paper argues that in addition to the successful economic reforms since 1978 or 1980, respectively, socioeconomic factors such as cultural values, the accumulation of social capital and the existence of social networks are an important impetus of long-term international competitiveness and economic development. Therefore, conditions and formation of socioeconomic factors in China and India were compared.

Both countries profit from cultural values conducive to economic development as, for example, appreciation of work and education. However, both nations lack social capital. In India, this is due to a pluralist society and the archaic caste thinking. This problem is not easily accessible for policy measures. Although the government tries to promote contracts between all social groups and access to jobs and institutions for the so-called scheduled castes, success remains low. In contrast, violent conflicts between different religious and social groups appear again and again. This aggravates the development of a common economic orientation.

In China, a more homogenous society and the hierarchical political system help introducing common national targets. This does, however, not necessarily represent the public opinion. Continuing governmental interference in social concerns as well as lacking autonomy of economic actors deplete the accumulation of social capital and the formation of social networks.

In contrast to pluralistic structures of society in India this is, however, a problem the Communist Party can deal with and may solve in granting greater freedom to its people. Therefore, socioeconomic structures in China have the potential to develop more positively than in India, constituting a competitive advantage in the long run.

Closing, one fact is especially apparent. Positive values and norms in the sense that they are conducive to economic progress are more likely the higher the educational level. Thus, access to education and knowledge will be the most crucial issue in economic politics in the future.

\section{References}

[1] D. Wilson and R. Purushothaman, "Dreaming with BRICs: the path to 2050," Global Economics Paper 99, Goldman Sachs, 2003.

[2] B. R. Scott and G. C. Lodge, U. S. Competitiveness in the World Economy, Harvard Business School Press, Boston, Mass, USA, 1985.

[3] F. Fajnzylber, "International competitiveness: agreed goal, hard task," CEPAL Review, no. 36, pp. 7-23, 1988.

[4] WEF, Global Competitiveness Report 2003-2004, World Economic Forum, Geneva, Switzerland, 1999.

[5] J. Fagerberg, "International competitiveness," The Economic Journal, vol. 98, no. 391, pp. 355-374, 1988.

[6] J. E. Newall, "The challenge of competitiveness," Business Quarterly, vol. 56, no. 4, pp. 94-100, 1992. 
[7] His Majesty's Treasury, "International competitiveness," Economi Progress Report 158, pp. 1-3, 1983.

[8] R. Solow, "A contribution in the theory of economic growth," Journal of Economics, no. 1, pp. 65-94, 1956.

[9] P. M. Romer, "Endogenous technological change," Journal of Political Economy, vol. 94, no. 5, pp. 1002-1037, 1990.

[10] R. J. Barro and X. Sala-i-Martin, Economic Growth, McGrawHill, New York, NY, USA, 1995.

[11] A. Maussner and R. Klump, Wachstumstheorie, SpringerLehrbuch, Berlin, Germany, 1996.

[12] P. Aghion and P. W. Howitt, Endogenous Growth Theory, MIT Press, Cambridge, Mass, USA, 1998.

[13] J. Schumpeter, The Theory of Economic Development: An Inquiry Into Profits, Capital, Credit, Interest and the Business Cycle, Duncker \& Humboldt, Leipzig, Germany, 1912.

[14] J. Viner, The Customs Union Issue, Carnegie Endowment for International Peace, New York, NY, USA, 1998.

[15] U. Walz, Dynamics of Regional Integration, Physica, Heidelberg, Germany, 1999.

[16] P. R. Krugman and M. Obstfeld, International Economics. Theory and Policy, Addison-Wesley World Student Series, Boston, Mass, USA, 6th edition, 2003.

[17] M. E. Porter, The Competitive Advantage of Nations, vol. 1, Macmillan, London, UK, 1990.

[18] H. Gersmeyer, Wettbewerbsfähigkeit von Wirtschaftsstandorten unter besonderer Berücksichtigung industrieller Cluster, Peter Lang, Europäischer Verlag der Wissenschaften, Frankfurt, Germany, 2003.

[19] K. Esser, W. Hillebrand, D. Messner, and J. M. Stamer, Systemic Competitiveness - New Governance Patterns for Industrial Development, Frank Cass, London, UK, 1996.

[20] F. Fukuyama, "Culture and economic development: cultural concerns," International Encyclopedia of the Social \& Behavioral Sciences, pp. 3130-3134, 2001.

[21] J. D. Spence, The Search for Modern China, W.W. Norton \& Company, New York, NY, USA, 1990.

[22] Y. Qian, The Process of China's Market Transition (197898): The Evolutionary, Historical and Comparative Perspectives, Stanford University, Stanford, Calif, USA, 1999.

[23] D. Fischer and M. Schüller, "Wandel der ordnungspolitischen Konzeptionen seit 1949," in Länderbericht China, D. Fischer and M. Lackner, Eds., pp. 227-247, Bundeszentrale für politische Bildung, Bonn, Germany, 2007.

[24] M. Taube, "Wirtschaftliche Entwicklung und struktureller Wandel seit 1949," in Länderbericht China, D. Fischer and M. Lackner, Eds., pp. 248-264, Bundeszentrale für politische Bildung, Bonn, Germany, 2007.

[25] P. Bottelier, "Twenty five years of economic reform in China," Perspectives, vol. 5, no. 4, pp. 46-54, 2004.

[26] J. B. DeLong, "India since independence: an analytic growth narrative," in Search of Prosperity: Analytical Narratives on Economic Growth, D. Rodrik, Ed., pp. 184-204, Princeton University Press, Princeton, NJ, USA, 2003.

[27] A. Panagariya, "India in the 1980s and 1990s: a triumph of reforms," Working Paper 04/43, IMF, 2004.

[28] D. Rodrik and A. Subramanian, "From Hindu growth to productivity surge: the mystery of the Indian growth transition," Working Paper 10376, NBER, 2004.

[29] A. Rose and C. Grupe, China-Indien: Wettbewerbsfähigkeit im Vergleich, Peter Lang, Frankfurt am Main, Germany, 2009.

[30] T. Geiger and S. P. Rao, The India Competitiveness Review 2009, World Economic Forum, 2009.

[31] D. E. Bloom, D. Canning, L. Hu, Y. Liu, A. Mahel, and W. Yip, "Why has China's economy taken off faster than India's," in
Proceedings of the Annual Meeting of the American Economic Association in Boston, 2006.

[32] B. Bosworth and M. C. Susan, "Accounting for growth: comparing China and India," Research Working Paper 12943, National Bureau of Economic, 2007.

[33] D. Bronger and J. Wamser, Indien-China Vergleich zweier Entwicklungswege, LIT, Muenster, Germany, 2005.

[34] J. C. H. Chai and K. C. Roy, Economic Reform in China and India: Development Experience in a Comparative Perspective, Edward Elgar Publishing, Northampton, Mass, USA, 2003.

[35] D. K. Das, China and India-A Tale of Two Economies, Routledge, New York, NY, USA, 2006.

[36] M. Desai, "India and China: an essay in comparative political economy," in Proceedings of the IMF Conference on India/China, Delhi, India, November 2003.

[37] H. Fromlet, "India versus China-who will be the winner in the long run?" Economic \& Financial Review, vol. 12, no. 3, pp. 111-143, 2005.

[38] B. Gilley, "Two passages to modernity," in Asia's Giants: Comparing China and India, E. Friedman, Ed., pp. 19-52, Palgrave Macmillan, Basingstoke, UK, 2006.

[39] T. Khanna and Y. Huang, "Can India overtake China?" Foreign Policy, no. 137, pp. 74-81, 2003.

[40] S. Long, "The Tiger in Front: A Survey of India and China," The Economist, 2005.

[41] A. Panagariya, "Why India lags China and how it can bridge the gap," in The world Economy, D. Greenaway, Ed., vol. 30, pp. 229-248, Blackwell Publishing, 2007.

[42] L. A. Winters and S. Yusuf, "Introduction: dancing with giants," in Dancing with Giants - China, India and the Global Economy, L. A. Winters and S. Yusuf, Eds., pp. 1-34, The International Bank for Reconstruction and Development/The World Bank and The Institute of Policy Studies, Washington, DC, USA, 2007.

[43] T. Brockmeier, Wettbewerb und Unternehmertum in der Systemtransformation: Das Problem des institutionellen Interregnums im Prozeß des Wandels von Wirtschaftssystemen, Schriften zu Ordnungsfragen der Wirtscahft, Band 59, Lucius \& Lucius, Stuttgart, Germany, 1998.

[44] D. North, Theorie des institutionellen Wandels, Mohr Siebeck, Tübingen, Germany, 1988.

[45] D. North, Institutionen, institutioneller Wandel und Wirtschaftsleistung, Mohr Siebeck, Tübingen, Germany, 1992.

[46] C. F. Camerer, Behavioral Game Theory: Experiments on Strategic Interaction, Princeton University Press, Princeton, NJ, USA, 2003.

[47] S. Heilmann, "Das politische System der VR China: Modernisierung ohne Demokratie?” in Länderbericht China, D. Fischer and M. Lackner, Eds., pp. 181-197, Bundeszentrale für politische Bildung, Bonn, Germany, 2007.

[48] O. Ihlau, Weltmacht Indien, Bundeszentrale für politische Bildung, Bonn, Germany, 2006.

[49] S. Ganguly, "Der indisch-pakistanische Konikt," Aus Politik und Zeitgeschichte, no. 22, pp. 32-38, 2008.

[50] Bertelsmann Stiftung, Bertelsmann Transformation Index 2006 India, Bertelsmann Stiftung, 2006, Discussion paper.

[51] D. H. Perkins, S. Radelet, D. R. Snodgrass, M. Gillis, and M. Romer, Economics of Development, Norton, London, UK, 5th edition, 2001.

[52] T. Scharping, "Bevölkerungspolitik und demographische Entwicklung," in Länderbericht China, D. Fischer and M. Lackner, Eds., pp. 50-71, Bundeszentrale für politische Bildung, Bonn, Germany, 2007. 
[53] Planning Commission Government of India, Eleventh Five Year Plan (2007-2012) Inclusive Growth, vol. 1, Oxford University Press, Neu Delhi, India, 2008.

[54] D. Yan, China's Employment Policies and Strategies, Chinese Academy of Labour and Social Security, 2006.

[55] P. Agrawal, "Indien: Quoten für Unberührbare," Le Monde diplomatique, vol. 11, no. 8272, pp. 17-18, 2007.

[56] S. Dunaway and A. Fedelino, "Fiscal policy in China," in China and India: Learning from Each Other-Reforms and Policies for Sustained Growth, J. Aziz, S. Dunaway, and E. Prasad, Eds., pp. 231-240, International Monetary Fund, Washington, DC, USA, 2006.

[57] P. Brian and F. Zahir, "India: why fiscal adjustment now," Research Working Paper 3230, World Bank Policy, 2004.

[58] E. Prasad, T. Rumbaugh, and Q. Wang, "Putting the cart before the horse? capital account liberalization and exchange rate flexibility in China," in China and India: Learning From Each Other-Reforms and Policies for Sustained Growth, J. Aziz, S. Dunaway, and E. Prasad, Eds., pp. 181-199, International Monetary Fund, Washington, DC, USA, 2006.

[59] S. Tharoor, Eine kleine Geschichte Indiens, Suhrkamp, Frankfurt, Germany, 2005.

[60] J.S. Coleman, "Social capital in the creation of human capital," The American Journal of Sociology, vol. 94, pp. 95-120, 1988.

[61] R. D. Putnam, “Tuning in, tuning out," Political Science \& Politics, vol. 28, no. 4, pp. 664-683, 1995.

[62] A. Rus, "Social capital and SME development," in Small Enterprise Development in South-East Europe, W. Bartlett, M. Bateman, and M. Vehovec, Eds., Policies for Sustainable Growth, pp. 39-69, Kluwer Academic Publishers, Dordrecht, The Netherlands, 2002.

[63] S. Knack and P. Keefer, "Does social capital have an economy payoff? A cross-country investigation," Quaterly Journal of Economics, no. 112, pp. 1251-1288, 1997.

[64] R. D. Putnam, Making Democracy Work-Civil Traditions in Modern Italy, Princeton University Press, Princeton, NJ, USA, 1993.

[65] K. Arrow, "Gifts and exchanges," Philosophy and Public Affairs, vol. 1, no. 4, pp. 343-362, 1972.

[66] J. S. Coleman, Foundations of Social Theory, Harvard University Press, Cambridge, Mass, USA, 1990.

[67] M. Raiser, “Trust in transition," Working Paper 39, European Bank for Reconstruction and Development, 1999.

[68] S. M. Lipset, "The social requisites of democracy revisited: 1993 presidential address," American Sociological Review, vol. 59, no. 1, pp. 1-22, 1994.

[69] M. Baurmann and R. Zintl, "Social and cultural preconditions of democracy: a framework for discussion," in Preconditions of Democracy, G. Brennan, Ed., pp. 19-74, Tampere University Press, Tampere, Finland, 2006.

[70] S. Huntington, "The clash of civilizations," Foreign Affairs, vol. 72, no. 3, pp. 22-49, 1993.

[71] S. Huntington, The Third Wave: Democratization in the Late Twentieth Century, University of Oklahoma, Norman, Okla, USA, 1991.

[72] S. N. Eisenstadt, "The protestant ethic theses in the framework of sociological theory and Weber's work," in The Protestant Ethic and Mod36 Ernization: A Comparative View, S. N. Eisenstadt, Ed., pp. 3-45, Basic Books, New York, NY, USA, 1968.

[73] R. Vanneman, J. Noon, M. Sen, S. Desai, and A. Shariff, "Social networks in India: caste, tribe and religious variations," in Proceedings of the Annual Meeting of the Population Association of America, University of Maryland College Park, Los Angeles, Calif, USA, March-April 2006.

[74] F. Fukuyama, "Social capital, civil society and development," Third World Quarterly, vol. 22, no. 1, pp. 7-20, 2001.

[75] R. Peerenboom, "Social networks, rule of law and economic growth in China," Global Economic Review, vol. 31, no. 2, 2002.

[76] M. Paldam and G. Tinggaard, "Missing social capital and the transition in Eastern Europe," Journal for Institutional Innovation, Development and Transition, 2001, 5.

[77] C. L. Hamrin, China's Social Capital Deficit, Global China Center, Charlottsville, Va, USA, 2006.

[78] The Chicago Council on Global Affairs, "The United States and the rise of China and India," Global Views, 2006.

[79] G. Hofstede and G. J. Hofstede, Culture and Organizations: Software of the Mind, McGraw-Hill, New York, NY, USA, 2nd edition, 2005.

[80] J. A. Schumpeter, Capitalism, Socialism, and Democracy, Harper and Row, New York, NY, USA, 3rd edition, 1950.

[81] T. Vanhanen, Prospects of Democracy: A Study of 172 Countries, Routledge, London, UK, 1997. 


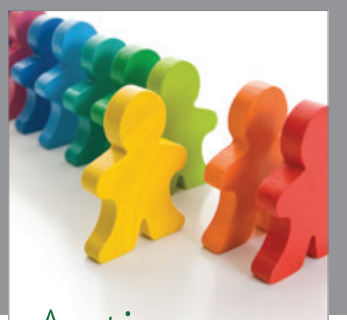

Autism

Research and Treatment
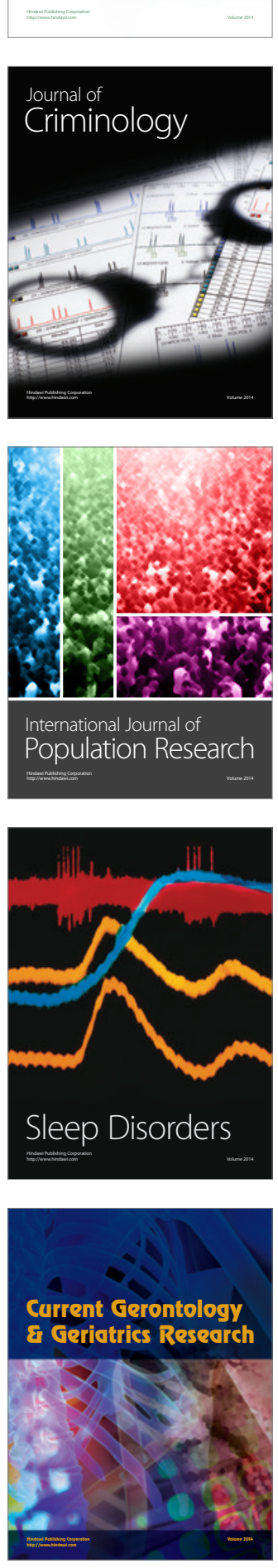
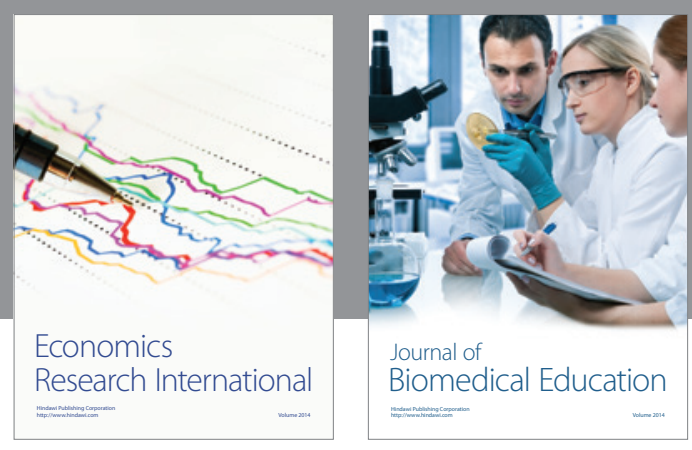

Journal of

Biomedical Education

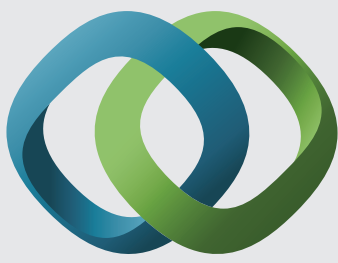

\section{Hindawi}

Submit your manuscripts at

http://www.hindawi.com
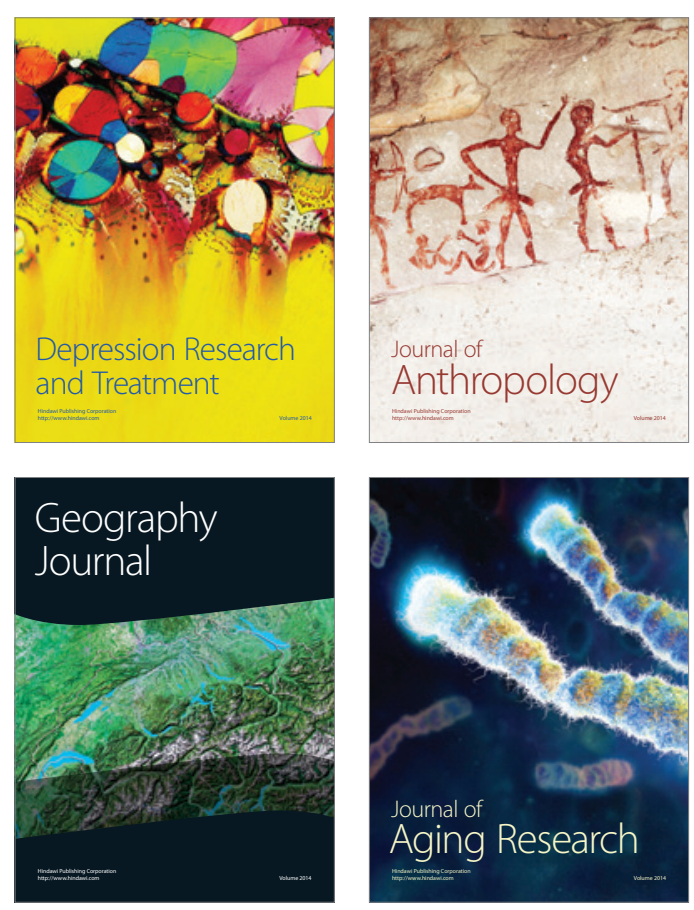

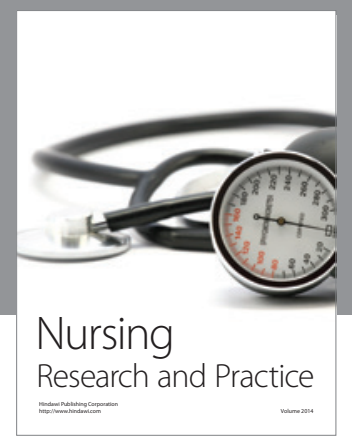

Nursing

Research and Practice

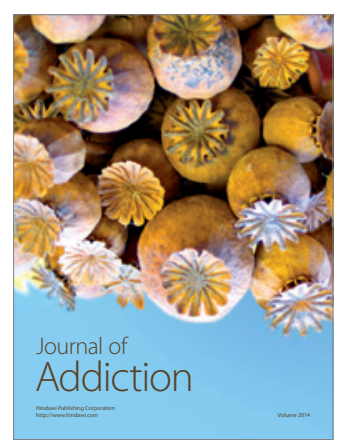

Child Development

Research

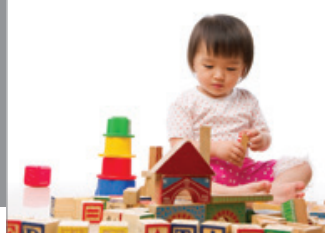

迥
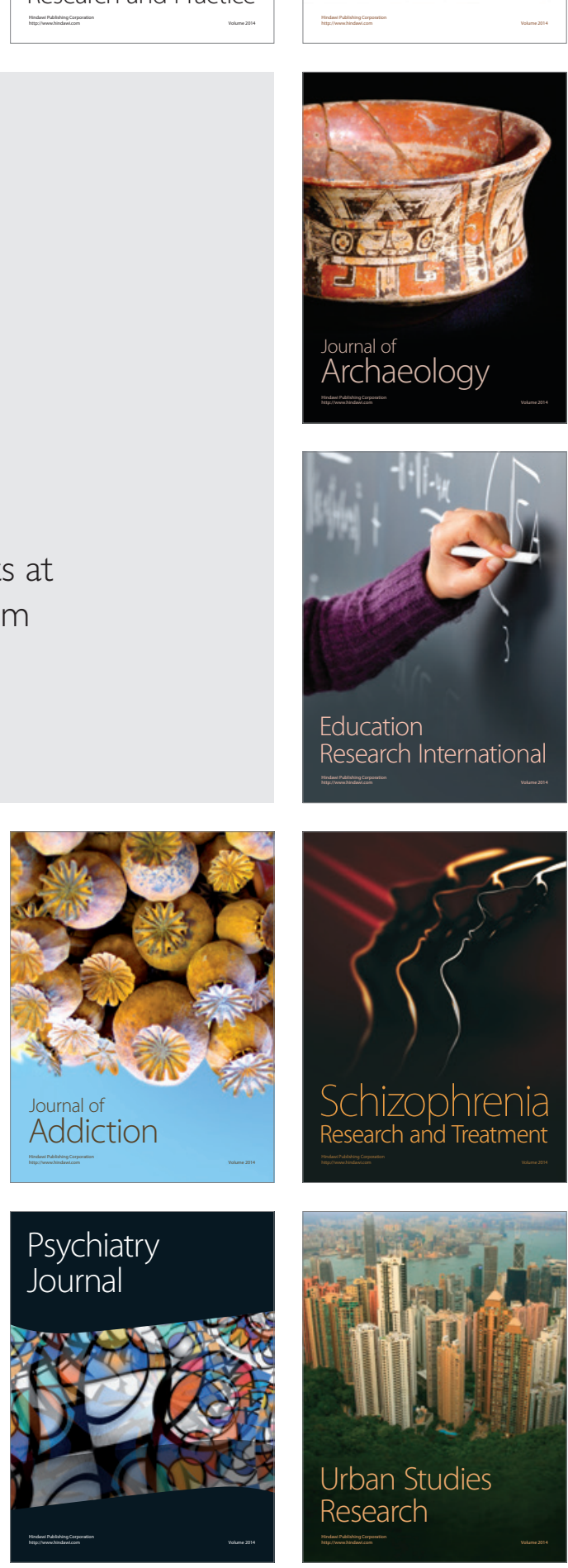